\title{
E-Learning: Justifications and Obstacles
}

\author{
$\underline{\text { http://dx.doi.org/ijet.v6i3.1610 }}$ \\ A. H. Khoury, L. M. Nasir Eddeen, D. S. Saadeh, and O. K. Harfoushi \\ University of Jordan, Amman, Jordan
}

\begin{abstract}
ELearning system or are thinking to adopt it in their educational systems. As a nearly recent system, many do not know the exact meaning of E-Learning, or why should it be used? After using it, will the institution face any problems? And what are the best solutions for these problems? This paper aims to answer all the above questions. In addition, it discusses the ways to transform traditional learning systems to E-Learning, and how to measure the advantages of this transformation. Finally, the students' views of E-Learning show that they prefer e-learning over traditional system.
\end{abstract}

Index Terms-CBT, E-Learning, ROI, WBT.

\section{INTRODUCTION}

The world is considered now days as a small village, full of information. Internet has succeeded to connect the whole world. In past days, human culture didn't see such connection and openness in information field. This has affected our lives in different aspects, and contributed to change the styles of our lives in unexpected way.

There are many factors that affect the traditional education, for example the traditional learning lectures need books or print outs, which are most of time very expensive and some times not available.

The learning field is one of the fields that has been most affected by this alternation. E-learning has become the worldwide appearance in different aspects of learning and training. This paper aims to summarize the main aspects concerning E-Learning. This includes answering the following questions: What is E-learning? What is the role of university environment in E-learning? Reasons for Elearning are discussed, then the common mistakes in application of E-learning are briefly discussed. After that, the proposed ways to overcome disadvantages of Elearning are listed, and to transform Traditional Learning Systems to E-Learning. Finally, the ways to view Students opinions in E-Learning are talked about.

\section{E-LEARNING:}

E-learning is a catch-all term that covers a wide range of instructional material that can be delivered on a CDRom or DVD, over a local area network (LAN), or on the Internet. It includes Computer-Based Training (CBT), Web-Based Training (WBT), Electronic Performance Support Systems (EPSS), and distance or online learning and online tutorials. There are some typical elements and standard approach to developing or authoring E-learning material.

E-learning has become the worldwide appearance in different aspects of learning and training. There are many distinguished forms of E-learning found on the Web in many universities around world. For example (not exclud- ing), Jones International University [4], The University of Manchester [7], RMIT University [8] and University of Phinox [5] are considered among leader universities in providing well organized E-learning systems.

There is no official definition of E-learning. In this paper, the most comprehensive definitions have been referred to. Al_Oweid and Al_Hamed define E-learning to be "the learning that aims to find the interactive environment full of applications dependent on computer technologies and Web; it enables the student to reach the learning resources at any time and any place" [6].

While, Al_Mosa defines E-learning as "a learning method that uses modern communication techniques, as a computer, computer networks, searching engines, $E$ libraries and multimedia as voice, image and graphics, either during or after semester" [6].

According to Liyoshi [9], the history of education is a narrative on opening up education. Recently, faculties, students, and educational institutions have advanced education in many ways using media and information communication technologies. So, some new terms have appeared like: Computer-Assisted Learning, Intelligent Tutoring Systems, Computer-Supported Collaborative Learning, interactive multimedia, telecommunications, and the Internet. All of these forms of technology have not only affected the Teaching-Learning process but have also extended educational chances.

Today, a convergence of events is creating the perfect environment for significantly advanced education. With a appearance of widely available educational tools and resources, and with an increasingly connected community, transformative opportunities for education grow. Now, we see a large number of new initiatives with the potential to totally change the ecology and the economics of educational process.

It means that different kinds of technology can be used to transfer the information to the educator in shortest time, least effort and maximum benefits.

\section{REASONS FOR E-LEARNING:}

Application of E-learning can be justified by the following reasons:

1. The major advantage to students is its easy access: E-learning provides the student or learner with information that can be accessed in a setting free from time and place constrains. The student goes through the lessons at his or her own place.

2. Increasing ability of communication: between students, and between students and faculty members through E-mails, discussion boards and conference 
rooms. All these push students to participate and interact with the subject under study.

3. Contribution of students in different points of view: conference rooms and forums give the opportunity to exchange points of view in different raised subjects, which increases the utilization of the ideas and presented suggestions which can be merged with students' own ideas. This increases production of strong base of knowledge for educator through what he has gained of skills and knowledge through discussion rooms.

4. Feeling of evenness: Since the communication tools give every student chance to present his opinion any time without embarrassment, in opposite to traditional lecture rooms in which student may feel uncomfortable because of disorganization of room seats, weakness in his voice, or any other reason. Elearning gives full opportunity for each student to share his/her ideas through sending them using communication tools as E-mail or conference room. This attribute is more beneficial for students who feel shame, afraid or worried, and this technique make students braver to express their thoughts. The studies have proved that this kind of discussion encourages the students to confront.

5. Easiness in reaching lecturer or teacher: Using Elearning it's easier to reach the teacher at any time, even out of his working hours, since the student is able to send his questions and inquires using E-mail. This is also beneficiary to students whose working hours conflict with teacher's office hours, or when student has any questions which can't be postponed.

6. Ability to modify teaching method: The teacher is able to present his subject in any way that is closer and more proper for students. Some students prefer visual type of presentation; others prefer it to be audible or readable, others scientific. E-learning and its sources has the ability to apply the sources in any way and apply the best technique to be most efficient for the beneficiary.

7. E-learning subjects are well-arranged: which gives opportunity to focus on important thoughts through gathering and writing the lecture. It also gives the opportunity to the students that have difficulties in focusing and organizing. E-learning subjects are well-arranged and coordinated in easy and neat way, with distinguished important elements.

8. Ability to repetition: This is additional characteristic to all who learn in scientific way, by training. So when then try to express their thoughts, they put them in sentences, which means they repeat the information they practiced on, as when students study for exam.
9. Ability to reach the curriculum any time: each day of week, 24 hours a day. This is big opportunity for all moody persons who like to study at day time or night time and those who have personal responsibilities. So E-learning enables every one to study any time.

10. Reaching the curriculum on continuous pattern: This characteristic makes the student stable, since he can reach any information he needs any time. He is not bound by the opening or closing hours of the library, which makes the student more comfortable and stable.

11. Being independent on physical attendance: In traditional education the student has to be committed with an actual schedule and he is forced to group work. E-learning has offered the ability for the student to participate the lecture without being physically there.

12. Easiness and variety to evaluate students' development: The immediate evaluation tools offered to the teacher a wide range of ways to build, organize and distribute information to be easily and quickly evaluated.

13. Taking highest benefits of time: Time saving is very important for both sides; teacher and student. Since the student is able to reach immediately the information anytime and anywhere, so there is no need to go to lecture rooms or libraries or teachers' offices, which saves lots of time. The same is considered on teachers' side, who can send all students' needs through immediate communication lines.

14. Reducing administration jobs for teachers: The paper work, as gathering home works or checking absence, takes a lot of teacher's time in traditional working. E-learning has reduced all these jobs by sending and receiving all of them using electronic tools.

15. Reducing the volume of faculty administration works: E-learning has presented the tools needed to analyze the results and marks which can be immediately sent to the registrar.

\section{Mistakes in ApPlicAtion Of E-LEARNing:}

Lack of planning, the absence of good vision and rashness are the most important factors that lead to project failure [9].

There are some mistakes that must be avoided, since any of them can lead to the damage of E-learning project, which is unacceptable since the main victim of E-learning is the student.

The main mistakes can be summarized as follows:

- Taking the decision of application of E-learning by the higher management, without sharing this decision 
with all sides that share this operation as dean, department president and educators themselves.

- Taking the decision without preparing the workers of the educational foundation for the application of Elearning, without convincing them of its importance and necessity for the development of educational process, and without defining the roles of workers and training them on the new tools used.

- The lack of clear and precise planning that contains project definition, goals, execution tools, application stages and budget needed for each stage, and determining committees which will be responsible for execution and maintenance of project.

- Concentration of the goals on material return or on decreasing the burden on student, and ignoring students' knowledge and scientific outcome.

- Application of E-learning on all subjects taught in particular semester. There are some subjects for whom E-learning process is unsuitable and application of typical learning is more effective, especially mathematical subjects that use symbols and need solving problems.

- Inserting new additional technologies without usage of the existing technologies in a proper way.

- Ensuring the best and most expensive software and equipment without finishing the training process. This means that the advantage taken from the software and equipment will not be at maximum level.

- The lack of using assessment from time to time to make sure that the goals are achieved properly.

\section{DisAdVAnTAGeS AND DeFECTS OF E-LEARninG:}

The E-learning process depends on Internet, so to understand the disadvantages of E-learning, we have to realize that Internet is a communication tool and it's an open system that contains information from any source. Any person can be owner of Internet site on which he can publish any kind of information correct or incorrect.

So since Internet is an open system, it can provide useful information such as researches, on the other hand it can provide other harmful information too.

The institutions that depend on E-learning have to be aware that all information on that open system will be available for the students.

The main disadvantages of E-learning are:

- Since the Internet contains correct and other incorrect information, so the quality of the knowledge can be affected.

- Lack of resources and technologies and infrastructure for communication.

- Lack of teachers with high Internet experience.

- Students can easily reach any research or information with less effort than manually, which makes the students to get used to laziness.

- Opposition of society to E-learning thought.

- Lack of security.

\section{WAYS TO OVERCOME DISADVANTAGES OF E- LEARNING:}

The ways to overcome previously mentioned disadvantages are:
- Using methodical approach in instructional authoring of E-Learning:

- Material should be clear and consistent.

- The user interface should be intuitive and easy to navigate.

- $\quad$ There should be ongoing and purposeful interaction with and by student.

- Real-world applications, exercises and examples are necessary.

- $\quad$ There must be an effective and systematic assessment of student progress.

- Multimedia should be used primarily to effectively communicate content and motivate learning.

- Reducing the total cost of using E-learning technology: The used technology is expensive, but on the other side it shouldn't be seen as so expensive when used well to provide services. All educational associations as schools and collages should realize that without internet it will be isolated from the outside world.

In the near future most students will be able to study in one of schools or universities without leaving home; in this case all the schools that decided not to invest in Internet will be not able to follow this program.

- Controlling the technology: Since all educational systems are characterized in controlling, so it's possible to control everything attached to E-learning as the resources and educational quality and educational trust.

- Using unforgivable restricted policies about educational trust and against everyone who breaks the rules.

- Using restricted security policy: It's the ability to recognize who is and who isn't allowed to reach the information and necessity to obey this policy using different ways as firewall which is software to control Internet access.

- Teaching and training all educators: It's a special training in using technology and Internet besides training in teaching techniques and methods.

- Convincing the community about the importance of this technology: this also includes convincing the community about technology's ability to serve the community and to achieve better future.

\section{TRANSFORMING TRADITIONAL LEARNING SYSTEMS TO E-LEARNING}

Any university management should see a measurable return from the money spent on producing and delivering E-Learning system. A wide spread measurement tool is ROI. ROI stands for "Return on Investment", and it is used to perform a comparison for the E-Learning system with the standard classroom training. [2]. The ROI is calculated by comparing the development cost of the E-Learning with a measurement of increased productivity. 
Creating custom E-Learning courseware costs significantly more than creating standard training, according to many studies, for example as Ref. [16]. Using multimedia in Web-based training can also increase the cost. Factors in determining the cost per E-Learning page or screen include writing the content, designing the page and adding illustrations, and producing multimedia effects, if used. But the time the student must spend being trained is reduced by about $40 \%$ using E-Learning. So, students learn better with E-Learning. They remember what they learn more accurately and longer (retention) and they are better able to use what they learn to improve their performance (transfer) [2].

Across many different studies and reports from the military, education and industry show 15-25\% increases the learning achievement [3]. So according to Boggs [3], it can be concluded that ROI for E-Learning can be $50 \%$ $60 \%$ greater than the traditional training system.

The development of the online course required taking a class offered by Faculty Instructional Technology Staff (FITS) on how to create simple web pages with image links using WebCT [11]. WebCT offers full online delivery capability including threaded discussions, student websites, live chat rooms, and secure testing in any format. The development of online courses usually flows from "web enhanced" on-ground classes to full development of all course materials in online format. Issues associated with this transition include: 1) factors to consider in developing an online course; 2) mechanics of developing an online course; 3) advantages and disadvantages of teaching online; 4) online testing; 5) online grading; and 6) pedagogical and technical aspects of using the discussion board, testing online, surveys, and group presentations [10].

Many associations have adopted the building and developing of Strategies to Transform Learning Systems. As example, FuturEd [1], which is a consulting firm based in Canada, since 1995.FuturEd provides a great range of services related to all aspects of education and training in the future across Canada and around the world. According to FutureEd, it can do for any educational organization the main following services: it introduces the organization to the future, connects it to Canada's education and training community, links the organization to international change initiatives, provides complete project management, and finally meets the organization's research and development needs.

\section{STUdENT VIEWS OF E-LEARNING}

Many studies have been developed to collect the opinions of students regarding E-Learning to maintain an understanding of the views of students at many universities. In order to do so, many surveys have been organized of a sample of students who were taking courses that had an Elearning environment. As these groups of students were known to be using various forms of e-learning in their courses, studies were a good place to begin a deeper exploration of their views, expectation and experiences. The results then would give researchers a solid basis of evidence about the student perspective to add and discuss the issues involved in the implementation of e-learning systems. Many examples can be found in [11], [12], [13], [14], and [15].

\section{REFERENCES:}

[1] K. Barker, "Quality Assurance and E-learning", March 5, 2002, http://www.futured.com.

[2] R. Kurtus, "Return on Investment (ROI) From E-Learning", 2002, http://www.school-for-champions.com/elearning/roi.htm

[3] D. Boggs, "E-Learning Benefits and ROI Comparison of ELearning vs. Traditional Training", June, 2004, Whitepapers on Web-Based Training Topics, https://www.syberworks.com/

[4] Jones International University website, http://www.jiu.edu/ .

[5] University of Phinox website, http://www.phoenix.edu/.

[6] A. Al-Mousa, "E-Learning: Concepts, characteristics, Advantages, Disabilities...", "School of Future" Symposium, King Saud University, 22-23/10/2002.

[7] University of Manchester website, www.manchester.ac.uk.

[8] RMIT University website, www.rmit.edu.au

[9] T. Iiyoshi and M. S. Vijay Kumar, Opening Up Education: The Collective Advancement of Education through Open Technology, Open Content, and Open Knowledge, October, 2010. The MIT Press Cambridge, Massachusetts, London, England. ISBN-10: 0262-51501-6.

[10] B. C. Rambo-Igney, "Online Learning: Ready or Not Here I Come", 14th Annual Instructional Technology Conference, Middle Tennessee State University, USA, 2009.

[11] J. Haywood et el., "Student Views of E-Learning: A Survey of University of Edinburgh WebCT Users 2004", Scottish Centre for Research into On-Line Learning and Assessment, February, 2004.

[12] T. D. Lundgrenand, and K. S. Nant, "Student Attitudes toward Internet Courses: A Longitudinal Study." Journal of Computer Information Systems 43(3), 2003, pp. 61-66.

[13] K. S. Hong, "Relationships between students' and instructional variables with satisfaction and learning from a Web-based course." The Internet and Higher Education 5(3), 2002, pp. 267281. http://dx.doi.org/10.1016/S1096-7516(02)00105-7

[14] T. D. Lundgren, and K. S. Nantz, "Student Attitudes toward Internet Courses: A Longitudinal Study." Journal of Computer Information Systems 43(3): 61-66. 2003.

[15] H. Macleod, et el. "Gender and Information and Communications Technology - a 10 year study of new undergraduates", Techtrends, 46(6) 11-15, Association for EducationalCommunications and Technology (AECT), 2002.

[16] D. Barker, "Canadian Recommended E-Learning Guidelines". Vancouver: Future and Canadian Association for Community Education, 2002.

\section{AUTHORS}

A. H. Khoury is a teacher in Computer Science department in king's Abdullah II school for Information Technology at University of Jordan, Amman, Jordan (11942) (e-mail: ansar@ju.edu.jo).

L. M. Nasir Eddeen is a teacher in Computer Science department in king's Abdullah II school for Information Technology at University of Jordan, Amman, Jordan (11942) (e-mail: Lubna@ju.edu.jo).

D. S. Saadeh was an instructor in Computer Science department in king's Abdullah II school for Information Technology at University of Jordan, Amman, Jordan (11942) (e-mail: doaa_saadah@yahoo.com).

O. K. Harfoushi is an assistant professor in Business Information Systems department in king's Abdullah II school for Information Technology at University of Jordan, Amman, Jordan (11942) (e-mail: o.Harfoushi@ju.edu.jo).

Received. Published as resubmitted by the authors August $2^{\text {nd }}, 2011$. 